\title{
USING TRANSPORT POLICY TO INCREASE PHYSICAL ACTIVITY
}

\author{
Roger L Mackett, Centre for Transport Studies, University College London, Great \\ Britain, Email: r.mackett@ucl.ac.uk
}

\begin{abstract}
The objective of this paper is to consider whether transport policy can contribute to the improvement of health by increasing walking and cycling and hence levels of physical activity in a way that is likely to be effective and acceptable to the public. The work is based on a project carried out for the UK Department for Transport to review the available evidence on the role of transport in increasing levels of physical activity. A key feature of this approach would be to shift people from the car to the alternatives of walking, cycling and use of local public transport. In the paper, the direct contribution of travel to physical activity is discussed, and then the barriers to active travel are examined. Then a range of transport policy options are considered including the impact of the various policy options on walking and cycling.
\end{abstract}

Keywords: policy, car use, physical activity, active travel, walking, cycling

\section{INTRODUCTION}

In many countries of the world there is increasing concern about the effects of lack of physical activity on health, for example, through research into cardio-vascular disease (Paffenbarger et al, 1993), with inactivity being a leading cause of premature death and disability in developed countries (Murray and Lopez, 1996). Whilst it has been long been recognized that participation in sport can contribute to physical fitness, it was only in 1996 that the contribution of everyday physical activity to health was recognized (US Surgeon General, 1996). It was explicitly acknowledged that it need not be strenuous to achieve health benefits and that it can include walking and cycling. Since walking and cycling are part of transport, it follows that actions and policies developed by transport professionals that increase walking and cycling can contribute to addressing the significant health issues related to lack of physical activity being faced in many developed countries. The purpose of this paper is to consider the barriers to increasing levels of walking and cycling and how they can be overcome through transport policy interventions. This paper stems from a review of the literature and policy on transport, physical activity and health carried out for the British Department for Transport (Mackett and Brown, 2011). In the review it was found that much research has been carried out by physical activity researchers into the effect of interventions to influence individual behaviour on volumes of physical activity. It has been found that

$13^{\text {th }}$ World Conference on Transport Research, Rio de Janeiro, Brazil, 15-18 July, 2013 


\section{Using transport policy to increase physical activity \\ MACKETT, Roger L}

interventions need a supportive social environment to be effective but there have been found to be two problems: cost effectiveness has not been demonstrated for most of the interventions and there is a need for on-going investment for them to be sustainable. However, if policies and the resulting actions are being implemented for transport reasons, such as the relief of traffic congestion, and they also increase walking and cycling, they may be sustainable and cost-effective, since any significant investment in transport schemes will have been evaluated and the benefits shown to be greater than the costs. The evidence on the effects of transport policies and schemes on walking and cycling considered in this paper comes from around the world, but the focus of the policies is on experience in Great Britain. However, many of the ideas and concepts are applicable elsewhere in the world.

\section{THE DIRECT CONTRIBUTION OF TRAVEL TO PHYSICAL ACTIVITY}

Brisk walking has been shown to protect physical health, particularly if done consistently (Saelens et al, 2003; Wagner et al, 2001), with 30 minutes a day of moderate physical activity, including brisk walking, five days a week providing the activity required to remain fit (Haskell, et al, 2007; Marshall, et al, 2009). Later evidence showed that it need not be done in a single bout of 30 minutes a day but could be accumulated through shorter bouts (Murphy et al, 2009), such as several walks over the day, that walking and cycling can provide sufficient activity to meet the criteria (Adams, 2010) and that any intensity of walking can contribute to keeping fit (Tudor-Locke et al, 2011). One advantage of walking over some other types of physical activity is that it can be done without any preparation or special equipment. Zunft et al (1999) have argued that it also avoids the perception of being 'sporty' which might deter some people. Cycling provides similar benefits: for example Andersen et al. (2000) showed that those who cycled to work reduced the risk of all-cause mortality to $72 \%$ of that of those who did not commute by bicycle.

Other forms of travel such as public transport include walking: Besser and Dannenberg (2005) showed that Americans using public transport obtained significant volumes of physical activity through walks to access public transport, with 29\% reaching the 30 minute a day threshold just through these trips. Wener and Evans (2007) compared levels of physical activity between car and rail commuters and found that the latter were four times more likely to walk 10,000 steps a day than car commuters.

The evidence cited above suggests that using the car rather than walking, cycling or using public transport will involve less physical activity than the alternatives. Wennberg et al. (2006) found that regular car commuting was associated with increased risk of myocardial infarction (heart attack) compared with commuting by bus, walking and cycling and Saelens et al. (2003) found that car use explained variation in levels of physical activity. It should, however, be acknowledged that use of the car enables people to reach places where they can be active such as gyms and open countryside and there is evidence (Ellaway et al, 2003) that people living in car owning households have better health than those living in households without a car.

$13^{\text {th }}$ World Conference on Transport Research, Rio de Janeiro, Brazil, 15-18 July, 2013 
It can be seen in Table 1 that there has been a long-term shift from walking, cycling and local bus to the car in Great Britain. It can be seen that there has been a levelling off in car use, and possibly a slight upturn in the use of bicycles and local bus since 2005, suggesting that policies to shift people from the car might be beginning to have an impact, but the longterm trend has been a shift towards the car from the other modes.

Table 1 - Percentage of trips per head per year by each mode in Great Britain

\begin{tabular}{|l|c|c|c|c|c|}
\hline & $\mathbf{1 9 7 5 / 7 6}$ & $\mathbf{1 9 8 5 / 8 6}$ & $\mathbf{1 9 9 5 / 9 7}$ & $\mathbf{2 0 0 5}$ & $\mathbf{2 0 1 0}$ \\
\hline Walk & 35 & 34 & 27 & 24 & 23 \\
\hline Bicycle & 3 & 2 & 2 & 1 & 2 \\
\hline Local bus & 11 & 8 & 6 & 6 & 7 \\
\hline Car & 46 & 50 & 61 & 64 & 64 \\
\hline Other & 5 & 5 & 4 & 5 & 5 \\
\hline Total & $\mathbf{1 0 0}$ & $\mathbf{1 0 0}$ & $\mathbf{1 0 0}$ & $\mathbf{1 0 0}$ & $\mathbf{1 0 0}$ \\
\hline
\end{tabular}

Source: Department for Transport (2012)

As Table 2 shows, people who drive make fewer walking trips than those who do not (equivalent figures are not available for cycling) and it was shown above that walking and cycling contribute positively to health through physical activity relative to car use, so it is reasonable to deduce that a significant factor in the decline in health relating to physical activity is due to the shift from walking, cycling and use of local public transport to use of the car. This is confirmed by the evidence reviewed in Mackett and Brown (2011). Much of this paper will be concerned with transport policies which might help to reverse this process.

Table 2 - Number of trips walked per year per head by people with different levels of car ownership

\begin{tabular}{|l|c|c|c|c|}
\hline \multirow{2}{*}{} & \multirow{2}{*}{$\begin{array}{c}\text { People in } \\
\text { households without } \\
\text { a car }\end{array}$} & \multicolumn{3}{|c|}{ People in households with cars } \\
\cline { 3 - 5 } & 312 & Main drivers & $\begin{array}{c}\text { Other } \\
\text { drivers }\end{array}$ & Non drivers \\
\hline Number of trips & 3160 & 179 & 232 \\
\hline
\end{tabular}

Source: Department for Transport (2012)

Given how easy it is to walk, the question arises as to why more people do not do it, given that the message about obesity and the need to be more active has been spread very widely. The barriers to walking and cycling (or 'active travel') will be considered in the next section.

\section{THE BARRIERS TO ACTIVE TRAVEL}

If people are going to walk or cycle more, they will either be making new trips or switching from other modes. Whilst it is possible some people may make some new walking or cycling trips in order to improve their health or for other reasons such as a change to a more local job, it seems likely that most people will be switching trips that they already make from other modes to walking and cycling. Since walking and cycling trips tend to be relatively short, it is

$13^{\text {th }}$ World Conference on Transport Research, Rio de Janeiro, Brazil, 15-18 July, 2013 
sensible to concentrate on these trips. In Great Britain, $66 \%$ of trips in Great Britain are less than $8 \mathrm{~km}$ (5 miles) in length and over half of these are by car (Department for Transport, 2012), as shown in Table 3.

Table 3 - Trips by mode and trip length in Great Britain, $2011(\%)$

\begin{tabular}{|l|c|c|c|}
\hline \multirow{3}{*}{ Walk } & Less than $\mathbf{8 ~} \mathbf{~ m}$ (5 miles) & $\mathbf{8 ~} \mathbf{~ k m ~ ( 5 ~ m i l e s ) ~ o r ~ m o r e ~}$ & Total \\
\cline { 2 - 4 } & 23.1 & 0.0 & 23.1 \\
\hline Bicycle & 1.4 & 0.3 & 1.7 \\
\hline Bus & 4.4 & 2.3 & 6.7 \\
\hline Car & 35.8 & 27.7 & 63.5 \\
\hline Other & 1.7 & 3.2 & 4.9 \\
\hline Total & $\mathbf{6 6 . 4}$ & $\mathbf{3 3 . 5}$ & $\mathbf{1 0 0 . 0}$ \\
\hline
\end{tabular}

Source: Department for Transport (2012)

The reasons why so many people drive short trips (less than five miles or $8 \mathrm{~km}$ ) were identified in a project that was carried out in the Centre for Transport Studies at UCL for the British Department for Transport (Mackett, 2003). As indicated in Table 4, the reasons can be summarised under three headings:

- Lack of motivation;

- Difficulties in walking and cycling;

- Lifestyle and shortage of time.

Table 4 - Reasons for driving a car for short trips

\begin{tabular}{|l|l|c|}
\hline Reason for driving the car & Summary reason & $\%$ \\
\hline I had heavy goods to carry & Lifestyle and shortage of time & 19 \\
\hline $\begin{array}{l}\text { I was giving a lift to a family member or } \\
\text { friend }\end{array}$ & Lifestyle and shortage of time & 17 \\
\hline I was short of time & Lifestyle and shortage of time & 11 \\
\hline It was a long way & Difficulties in walking and cycling & 11 \\
\hline It was convenient & Lack of motivation & 10 \\
\hline I needed the car for a further trip & Lifestyle and shortage of time & 9 \\
\hline I needed my car at work & Lifestyle and shortage of time & 5 \\
\hline The weather was bad & Difficulties in walking and cycling & 5 \\
\hline It was dark out & Difficulties in walking and cycling & 4 \\
\hline I was on a social trip & Lifestyle and shortage of time & 4 \\
\hline I was taking an elderly or ill person & Lifestyle and shortage of time & 3 \\
\hline I cannot manage without my car & Lack of motivation & 1 \\
\hline I felt unwell & Difficulties in walking and cycling & 0 \\
\hline I was taking the dog for a walk & Lifestyle and shortage of time & 0 \\
\hline $\begin{array}{l}\text { It was an unpleasant environment to travel } \\
\text { through }\end{array}$ & Difficulties in walking and cycling & 0 \\
\hline Total & & $\mathbf{1 0 0}$ \\
\hline
\end{tabular}

Source: Mackett (2003)

The lack of motivation arises because, faced with the alternative of making a (short) trip by car quickly, comfortably and protected from the weather, or walking or cycling which takes longer, requires effort and involves exposure to the weather, many people choose the car.

$13^{\text {th }}$ World Conference on Transport Research, Rio de Janeiro, Brazil, 15-18 July, 2013 


\section{Using transport policy to increase physical activity \\ MACKETT, Roger L}

This stems from the very widespread availability of the car, which arises partly from the relatively low marginal cost of making car trips: once people can afford a car, they tend to buy one.

There are several possible difficulties in making a walking or cycling trip:

- Physical difficulties;

- Fear of going out;

- The local environment is unsuitable;

- Desired opportunities are far away.

The physical difficulties stem partly from the increasing proportion of the population who are elderly, many of whom have difficulties walking. Others have disabilities that prevent them from walking (or cycling). Whilst some assistance may be given by walking sticks and similar equipment, many elderly people can only walk a limited distance. At any time, younger people can have difficulty walking, for example when carrying shopping or travelling with very young children. Many people shop in large supermarkets which mean that large volumes of shopping need to be carried home: for car owners, this is the most efficient way to transport the goods. There are places with high levels of street crime, but people reading stories about such crimes in newspapers may perceive that their local area is more dangerous than it really is. This may cause people not to walk or parents to forbid their children from doing so. Similarly, the perception of the risks caused by road traffic may be higher than reality. Streets with poor quality pavements, dog mess, chewing gum, and so on, do not make pleasant areas in which to walk. At night, streets lacking good lighting will discourage people from walking. People making a journey in daylight but returning after dark, may choose to use the car because of the return journey. As urban areas have spread, suburbs have developed, often providing housing with individual gardens where families can create their own environments largely free from interference from neighbours, with one or more garages. It is often possible to walk in such areas because they have suitable pavements and relatively low crime rates. However, densities are usually low, and so people tend not to live very near to the activities they need as part of their lives, such as employment, shops, schools and leisure facilities. Because they tend to have cars, the roads are often not very busy and the trips are relatively long, the mode of travel typically used is the car.

The shortage of time often relates to modern family life which has become very complex, partly because more mothers are employed, often part-time, and partly because there is a perceived need to protect younger children by not letting them out without adult supervision. This has led to the shift from free play to supervised structured activities for children. In the past children were allowed out to play alone or with friends. Now children tend to go to clubs, lessons and other organized activities. Because, unlike play, the structured activities occur in specific locations which are often not very close to home, and they often occur at specific times of day, such as after school, parents tend to use the car rather than walk to take their children there (Mackett et al, 2005).

The potential for switching modes from the car was examined in the project on short trips by car, as shown in Table 5 . The respondents said that $21 \%$ of trips could not be made by

$13^{\text {th }}$ World Conference on Transport Research, Rio de Janeiro, Brazil, 15-18 July, 2013 


\section{Using transport policy to increase physical activity MACKETT, Roger L}

alternative modes, but that $79 \%$ could have been made by the alternatives (Mackett and Ahern, 2000). Of the $79 \%$, the respondents said that $31 \%$ could have been walked, $7 \%$ by bicycle and $31 \%$ by bus, with the rest by other modes. This implies that there is considerable scope for more walking and cycling trips. It should be borne in mind that most bus trips include walking. The biggest factor that the respondents identified was improving bus services which was mentioned for $21 \%$ of the trips. The next most popular factor was 'No specific action' which can be interpreted as recognition that there is no specific barrier to using the alternatives, but it would be difficult for transport planners and others to implement policies and actions which could induce the change. For $10 \%$ of the car trips, the respondents recognised that they would need to make a change to their own behaviour to walk, cycle or use the bus more. There is little that can be done to improve the weather, but more shelters from the rain could be provided. Improvements to walking and cycling facilities were only identified for $2 \%$ and $1 \%$ of the short car trips respectively.

Table 5 - Factors that car users say could make them switch from car to walking and cycling (\% of all short car trips)

\begin{tabular}{|l|c|c|c|c|}
\hline Action & Walk & Cycle & Bus & Total \\
\hline Improve bus services & 0 & 0 & 21 & 21 \\
\hline No specific action & 12 & 2 & 5 & 19 \\
\hline Change own behaviour & 8 & 1 & 1 & 10 \\
\hline Better weather & 5 & 1 & 0 & 6 \\
\hline A reduction in the need to travel & 2 & 1 & 1 & 4 \\
\hline Better travel facilities for children and other dependents & 2 & 0 & 2 & 4 \\
\hline Improvements in walking facilities & 2 & 0 & 0 & 2 \\
\hline Improvements in cycling facilities & 0 & 1 & 0 & 1 \\
\hline Cancel activity & 1 & 0 & 0 & 1 \\
\hline Total & $\mathbf{3 1}$ & $\mathbf{7}$ & $\mathbf{3 1}$ & $\mathbf{3 8}$ \\
\hline
\end{tabular}

Source: Mackett and Ahern (2000)

Whilst it should be recognised that these answers are hypothetical, they do indicate that there is scope to shift people from the car to walking and cycling for short trips, particularly the former. The focus of that project was on factors that would attract drivers out of their cars to the alternatives rather than actions and policies to make car use less attractive or expensive. In practice, a combination of factors to make cars less attractive and the alternatives more attractive is likely to be required. There may also be a need to make those who use the car for short trips more aware of the ease and benefits of walking and cycling, especially the former. The rest of this paper is devoted to the examination of evidence on the effects of policies and actions by transport planners to increase levels of walking and cycling.

\section{EVIDENCE ON INTERVENTIONS TO INCREASE WALKING AND CYCLING}

There are a large number of reports and academic papers relating to walking and cycling. The National Institute for Health and Care Excellence (NICE) (formerly the National Institute for Health and Clinical Excellence) in London has carried out two studies to develop guidelines to improve health through increasing levels of walking and cycling. The role of

$13^{\text {th }}$ World Conference on Transport Research, Rio de Janeiro, Brazil, 15-18 July, 2013 


\section{Using transport policy to increase physical activity \\ MACKETT, Roger L}

transport and urban planning in increasing physical activity was addressed in the first study which involved the development of guidelines on 'Promoting and creating built or natural environments that encourage and support physical activity' (National Institute for Health and Clinical Excellence, 2008). A search of the data bases using a combination of transport and physical activity terms produced 19,376 references, with another 38 found by other means. When they had been assessed for relevance, whether they included an intervention related to modifying the physical urban environment and the quality of the data, 26 studies remained. Searches of electronic data bases using urban planning and design terms and physical activity terms together produced 23,714 titles. Another 35 were identified by other means. When they had been assessed for relevance, whether they included an intervention related to modifying the physical urban environment and the quality of the data, 13 studies remained. This illustrates the shortage of systematic studies of the effects of the built environment, including transport infrastructure, on physical activity. The second study by NICE has been conducted to examine local measures to promote walking and cycling as forms of transport or recreation (National Institute for Health and Clinical Excellence, 2012). In this study, 3729 papers that might be relevant were identified. These were reduced to 118 after assessment for relevance.

The interventions considered in the NICE report on interventions to promote cycling and walking (National Institute for Health and Clinical Excellence, 2012) included the use of the mass media, provision of health information, setting up led walks in the community, and schemes to provide pedometers (Blank et al, 2012). Whilst some of the interventions were found to be effective it is not clear how many of them would have continued to be effective without continuous investment of time and money. Those initiatives would not normally be the responsibility of transport planners, but some of the others were. The results from these two studies that are transport policies and schemes are summarised in Tables 6 and 7.

The evidence relevant to transport policy from the study on 'Promoting and creating built or natural environments that encourage and support physical activity' by NICE (National Institute for Health and Clinical Excellence, 2008) is summarised in Table 6. The review on urban planning and design (NICE Public Health Collaborating Centre, 2006b) found seven references on the effects of street infrastructure changes, such as pedestrianisation, on physical activity and two on setting up walking and cycling trails, for example using closed railway lines. In the transport review eight references were found on traffic calming, two on road user charging, four on combined walking and cycle paths, three on closing or restricting the use of roads, seven on improvements to cycling infrastructure and two on safer routes to schools (NICE Public Health Collaborating Centre, 2006a).

$13^{\text {th }}$ World Conference on Transport Research, Rio de Janeiro, Brazil, 15-18 July, 2013 
Table 6 - Impacts of transport policies and actions identified in the NICE review on Physical Activity and the Environment

\begin{tabular}{|c|c|c|c|c|c|c|c|}
\hline & $\begin{array}{l}\text { Number } \\
\text { of studies }\end{array}$ & $\begin{array}{l}\text { Number } \\
\text { studies v } \\
\text { term incr } \\
\text { walking }\end{array}$ & $\begin{array}{l}\text { fith short } \\
\text { ases in } \\
\text { cycling }\end{array}$ & $\begin{array}{l}\text { Number } \\
\text { studies v } \\
\text { term inc } \\
\text { walking }\end{array}$ & $\begin{array}{l}\text { f } \\
\text { ith long } \\
\text { ases in } \\
\text { cycling }\end{array}$ & Impacts & Methodological issues \\
\hline Traffic calming & 8 & 4 & 3 & 1 & 1 & $\begin{array}{l}\text { Small increases in walking and } \\
\text { cycling in five studies, but no } \\
\text { significant change or decreases in } \\
\text { three studies. }\end{array}$ & $\begin{array}{l}\text { Poorly reported methods in } \\
\text { four studies, other issues in } \\
\text { the other four studies. }\end{array}$ \\
\hline $\begin{array}{l}\text { Combined } \\
\text { walking and } \\
\text { cycle paths }\end{array}$ & 4 & 1 & 2 & 1 & 1 & $\begin{array}{l}\text { Evidence from three studies suggests } \\
\text { increases in walking and cycling in } \\
\text { long and short term, but one study } \\
\text { found decreases. }\end{array}$ & $\begin{array}{l}\text { Possible selection bias. Lack } \\
\text { of information on } \\
\text { confounders in two studies. }\end{array}$ \\
\hline $\begin{array}{l}\text { Trails (e.g. } \\
\text { converted } \\
\text { railway lines) }\end{array}$ & 2 & 1 & 1 & 1 & 0 & $\begin{array}{l}\text { Increases in physical activity in short } \\
\text { term and long term. }\end{array}$ & $\begin{array}{l}\text { Possible selection, recall and } \\
\text { measurement biases in both } \\
\text { studies. }\end{array}$ \\
\hline $\begin{array}{l}\text { Street } \\
\text { infrastructure }\end{array}$ & 7 & 3 & 2 & 1 & 0 & $\begin{array}{l}\text { Evidence of increased walking in four } \\
\text { studies, but two studies reported no } \\
\text { change and one reported a decrease } \\
\text { in walking. }\end{array}$ & $\begin{array}{l}\text { Possible measurement } \\
\text { and/or selection bias in all } \\
\text { studies. }\end{array}$ \\
\hline $\begin{array}{l}\text { Safer routes to } \\
\text { school }\end{array}$ & 2 & 2 & 2 & 1 & 1 & $\begin{array}{l}\text { Evidence of short and long term } \\
\text { increases in walking and cycling } \\
\text { within the area of the scheme. }\end{array}$ & Possible selection bias. \\
\hline
\end{tabular}

Source: NICE Public Health Collaborating Centre (2006a, b)

$13^{\text {th }}$ World Conference on Transport Research, Rio de Janeiro, Brazil, 15-18 July, 2013 


\section{Using transport policy to increase physical activity MACKETT, Roger L}

Table 7 - Impacts of transport policies and actions identified in the NICE review on local interventions to promote cycling and walking

\begin{tabular}{|l|c|c|c|c|l|}
\hline & $\begin{array}{l}\text { Number } \\
\text { of } \\
\text { studies }\end{array}$ & $\begin{array}{l}\text { Number of studies } \\
\text { with increases in } \\
\text { walking }\end{array}$ & cycling & Impacts & Methodological issues \\
\hline TravelSmart & 7 & 7 & 7 & $\begin{array}{l}\text { Increases of between } 11 \% \text { and } \\
29 \% \text { in walking and between 14\% } \\
\text { and } 69 \% \text { in cycling reported. }\end{array}$ & Limited figures on impacts. \\
\hline $\begin{array}{l}\text { Cycle Demonstration } \\
\text { Towns }\end{array}$ & $\begin{array}{l}3 \text { studies } \\
\text { on } 6 \\
\text { towns }\end{array}$ & 0 & 3 & $\begin{array}{l}\text { Increases in cycle counts of 12\% } \\
\text { on all routes and 60\% at specific } \\
\text { sites, and in proportion of adults } \\
\text { cycling. }\end{array}$ & $\begin{array}{l}\text { All reports on this topic have been removed from } \\
\text { the Department for Transport website because } \\
\text { of issues with the baseline data. }\end{array}$ \\
\hline $\begin{array}{l}\text { Sustainable Travel } \\
\text { Towns }\end{array}$ & $\begin{array}{l}\text { Walking increased by 10-13\%; } \\
\text { towns } 3\end{array}$ & 1 & 1 & $\begin{array}{l}\text { Some disagreements between the household } \\
\text { surveys and the manual counts. }\end{array}$ \\
\hline $\begin{array}{l}\text { University travel } \\
\text { plans }\end{array}$ & 1 & 1 & 1 & $\begin{array}{l}\text { Respondents usually walking to } \\
\text { work increased from 19\% to 30\%, } \\
\text { and cycling from 7\% to 12\% }\end{array}$ & $\begin{array}{l}\text { Changes for individuals cannot be determined. } \\
\text { Effects of individual strategies within the plan } \\
\text { cannot be determined. }\end{array}$ \\
\hline School travel plans & 2 & 1 & 1 & $\begin{array}{l}\text { Large impacts in one scheme, } \\
\text { none in the other. }\end{array}$ & $\begin{array}{l}\text { Lack of clarity about data collection in study } \\
\text { showing large impacts. Public transport grouped } \\
\text { with walking and cycling in other study. }\end{array}$ \\
\hline Safer routes to school & 1 & 1 & 1 & $\begin{array}{l}\text { Large increases in numbers } \\
\text { walking and cycling. }\end{array}$ & $\begin{array}{l}\text { Only two out of the 52 reported data for both } \\
\text { before and after. }\end{array}$ \\
\hline Bike It scheme & 1 & 0 & 1 & $\begin{array}{l}\text { Large increases in the number of } \\
\text { children cycling to school. }\end{array}$ & $\begin{array}{l}\text { Only percentage changes reported. Report is } \\
\text { written in promotional language and therefore } \\
\text { not critical. }\end{array}$ \\
\hline Walking school buses & 10 & 8 & 0 & $\begin{array}{l}\text { Increases in walking to school in } \\
\text { most cases but one showed no } \\
\text { effect. }\end{array}$ & $\begin{array}{l}\text { Various methodological issues such as small } \\
\text { sample sizes and short intervention periods. }\end{array}$ \\
\hline
\end{tabular}

Source: Blank et al (2012)

$13^{\text {th }}$ World Conference on Transport Research, Rio de Janeiro, Brazil, 15-18 July, 2013 


\section{Using transport policy to increase physical activity MACKETT, Roger L}

The largest intervention examined was the road user charging scheme in London. This followed a smaller scheme in Durham which was introduced on 1 October 2002 (Santos, 2004). The monitoring report (Durham County Council, 2003) found an $85 \%$ reduction in vehicular traffic and a $10 \%$ increase in pedestrian activity as a result of the $£ 2$ ( $€ 2.34$ ) charge introduced under the scheme. The London scheme started on 17 February 2003 (Santos, 2004). The scheme involves a charge of $£ 10$ ( $€ 11.72)$ a day (originally $£ 5$ then $£ 8$ ( $€ 5.86$ then €9.37)) for being within the charging cordon in the period from 7.00 to 18.00 on weekdays. It can be paid the day after the one on which the charge was incurred at a cost of $£ 12$ (€14.06). If this is not paid there is a penalty charge. Residents of the area receive a 90 per cent discount, but have to pay for a minimum of a week. There are various exemptions including buses and taxis. The scheme works by using cameras to read car registration plates automatically and comparing these with a list of those for which the charge has been paid. Penalty notices are sent out to those who are found not to have paid. No systematic evaluation of the scheme has been carried out, but, according to Transport for London (2008), the number of vehicles entering central London in 2007 was $16 \%$ lower than in 2002 , and the number of cars, minicabs and lorries fell by $29 \%$ in the same period. It was estimated that between $7 \%$ and $15 \%$ of car driver trips terminating in central London transferred to cycle, walk, motorcycle, taxi and car share (Transport for London, 2004). It is not clear how much of the reduction in car use actually transferred to walking and cycling. The congestion charging area was extended to the west on 19 February 2007. It was found that residents of the western extension zone who 'ever' walked increased by $4 \%$, and 'ever' cycling by $16 \%$ (Transport for London, 2008). In May 2008 Boris Johnson was elected Mayor of London in place of Ken Livingstone. This led to a review of the transport policies in London which led to the removal of the Western Extension to the congestion charge area on 4 January 2011 after a period of consultation.

Of the eight studies of the effects of traffic calming, five of the studies found increases in walking and cycling (Kirby 2001; Morrison et al. 2004; Scottish Office 1999; Webster et al. 2006) but two others found slight decreases (Social Research Associates 1999, 2001) and one found no significant change (Babtie Group 2001). The three references on the effects of closing or restricting the use of streets (Cairns et al. 1998a,b; Gemzoe 2001) all found long term increases in the levels of walking within the area of the scheme, and one found that it also increased the level of cycling. Of the references on street infrastructure changes, Layfield et al. (2003) and Newby and Sloman (1996) looked at the effect of improvements to the street environment on its use by pedestrians. The former examined the effectiveness of home zones and found an increase in the numbers walking and the numbers of children playing, but the evidence was not very strong. The latter reviewed the Feet First project and found that residents perceived that more people were walking, and that more children where playing. Skjoveoland (2001) looked at the impact of three street parks in a Norwegian city and found an increase in the number of children in one of the two newly-created parks (with no change in any of the three control parks), but the presence of adults decreased significantly in one of the new parks and in two of the three control parks. Space Syntax (2004a, 2004b) looked at pedestrian counts in two London squares that had been redesigned. An increase was found after the changes in one of the squares and a decrease in the other. Space Syntax (2002) also looked at the effect of a new pedestrian bridge across

$13^{\text {th }}$ World Conference on Transport Research, Rio de Janeiro, Brazil, 15-18 July, 2013 


\section{Using transport policy to increase physical activity MACKETT, Roger L}

the River Thames in London and found an increase in pedestrian activity as a result. Painter (1996) examined the influence of street lighting improvements on pedestrian street and footpath use in three areas in London and established that there were increased pedestrian counts.

The seven reviews on cycling infrastructure all found an increase in cycle use. Five of them found only an increase in cycling (Ashton-Graham 2003; Troelsen et al. 2004; Cope et al. 2003; Cycling Touring Club 1995a, 1995b), while one found a small increase in cycling and a significant decrease in walking (Mamoli 2003), and the other (Hartman 1990) found a small increase in cycling from a very high base and 'a likely decrease' in walking. Providing combined walking and cycle trails produced increases in walking and cycling in both the short and long run in three studies, but one other study found a decrease in walking and cycling following the introduction of the facility. The studies of new trails such as those created from former railway lines, were found to increase physical activity including walking. The two studies of safe routes to school (Sustrans 2005; Boarnet et al. 2005) both found that the introduction of the schemes led to short term increases in levels of walking and cycling within the area of the scheme.

Table 7 summarises the impacts of transport policies and actions identified in the NICE review on local interventions to promote cycling and walking (Blank et al, 2012). One set of schemes that was considered was TravelSmart, which uses 'individualised travel marketing' to identify travel choices that individuals may not have considered. According to Blank et al (2012) nineteen schemes in Britain were examined citing TravelSmart (2011) plus other reports on the same website but results are presented for only seven schemes. It is not possible to access the original reports but according to Blank et al (2012) the scheme appears to have produced annual increases in walking from $11 \%$ to $29 \%$ and increases in cycling from $14 \%$ to $69 \%$, with travel by car reduced by between $10 \%$ and $14 \%$, but the evidence on the methodologies used is rather limited.

Other initiatives examined include the Cycle Demonstration Towns (Cope, 2009, 2011; Sloman, 2009), the Sustainable Travel Towns (Sloman et al, 2010), Bike It, which is the set of initiatives set up by Sustrans (2008) to increase cycling by children, Safer Routes to School (Staunton et al, 2003) and school and university travel plans (Brockman and Fox, 2011). According to the Inside Government (2013) website the final reports on the evaluation of the Cycling City and Towns Programme have been withdrawn on the advice of the contractor responsible for collecting the baseline for the evaluation exercise, so it is not sensible to comment on the results of this initiative. One of the largest and most recent initiatives funded by the UK Department for Transport is the 'Sustainable Travel Towns' in which the three towns of Darlington, Peterborough and Worcester implemented packages of 'smarter choices' (Department for Transport, 2008). It is claimed that for the three towns together, from 2004 to 2008, there was a reduction of $9 \%$ in car driver trips and a reduction of $5 \%$ in car driver distance. Most of the reduction came from mode shift, but a small amount came from a net reduction in the number of trips. It was found that behaviour change was greatest amongst college students and people looking for work and least amongst those in employment. A more recent report presented information on the impact on walking and

$13^{\text {th }}$ World Conference on Transport Research, Rio de Janeiro, Brazil, 15-18 July, 2013 


\section{Using transport policy to increase physical activity \\ MACKETT, Roger L}

cycling (Sloman et al, 2010). It was found that, between 2004 and 2008, the percentage of respondents to the household travel survey who reported that they walked or cycled 'almost daily' increased from $46.6 \%$ to $49.4 \%$ and the number reporting that they 'almost never' walked or cycled fell from $23.4 \%$ to $20.9 \%$. However, it is not clear how robust the findings are because the study was commissioned before the Department for Transport had completed its guidance about how such schemes should be evaluated.

The university travel plan was found to increase walking and cycling to work, from $19 \%$ to $30 \%$ in the former case and from $7 \%$ to $12 \%$ in the latter. Very different results were found in the two studies looking at school travel plans. Cairns (2006) looked at one school and found that walking to school increased from $30.0 \%$ to $58.8 \%$ and that cycling increased from $0 \%$ to $4 \%$. In contrast, Rowland et al (2003) looked at 21 schools in a randomised controlled trial and found that the proportion of children walking or cycling to school was not affected by the intervention. The evaluation of safer routes to school in Marin County in the USA (Staunton et al, 2003) found increases of $64 \%$ in walking and $114 \%$ in cycling as a result the creation of safe routes to school using community-wide involvement with a full-time educator employed to develop the school curriculum.

The Bike It scheme involves the use of school travel plans and the use of cycling champions in schools to create a pro-cycling champion. The intervention has been evaluated for 52 schemes in Britain. It was found that the percentage of children cycling every day increased from $3 \%$ to $10 \%$, and the number who cycled once a week increased from $10 \%$ to $27 \%$, while the number who never cycled decreased from $80 \%$ to $55 \%$ (Sustrans, 2008). Ten studies of walking school buses were examined. Most of the studies showed a positive effect on the number of children walking to school up to 48 months after the intervention. However, there were various methodological issues such as small sample sizes and short period between the before and after studies to examine the impact of the intervention.

Whilst some of the increases in levels of walking and cycling appear to be large, they are likely to be spurious in many cases. A new scheme may appear to increase the levels of walking and cycling within the study area, but if the study area only includes the area covered by the scheme, and people are switching trips from elsewhere outside the study area, then the walking and cycling trips will not be newly generated and there be no increase in physical activity. For example, if a new walking and cycling trail is created on a disused railway line, and people who previously went elsewhere to walk and cycle start using the new facility and the evaluation is based on simply counting the number of trips observed using the facility, there is bound to be an overestimate of the impacts. As indicated in the tables, there are many methodological issues with the studies. Some of the soft measures such as TravelSmart seem to induced many walking and cycling trips, but Bonsall et al (2009) have questioned the reliability of the results of personal travel planning and argued that there may be systematic bias in the methods used 


\section{OTHER TRANSPORT POLICIES THAT MAY INCREASE WALKING AND CYCLING}

As well as the various interventions identified in the NICE studies a number of other initiatives which may increase levels of walking and cycling have been introduced in Britain.

A new approach to charging motorists has been introduced in Britain through legislation which permits the introduction of workplace parking levy schemes. The first one has been introduced in Nottingham with a levy charged on all employers who provide more than ten parking spaces from 1 April 2012 (Nottingham City Council, 2012). Employers can pay the charge from their resources or pass the cost on to their employees (or reduce the number of parking spaces). It is too early to say how effective this approach is being.

Car clubs appear to have a significant impact on car ownership and use whilst being run on a commercial basis according to Harmer and Cairns (2011) who carried out surveys in five car clubs with a total of 8,450 respondents. They found that one third of the respondents reduced the number of vehicles owned by their household since joining a car club. Compared with their behaviour before joining a car club, respondents made more frequent journeys by bicycle and public transport, but fewer walking journeys of 20 minutes or more, possibly because they are driving on some journeys they otherwise would have walked.

More recently, the present British Government has shown interest in encouraging behaviour change as a way of addressing some policy issues, reflecting the fact that humans do not always behave in ways that might be expected if they behaved rationally. This is based on consideration of explicit attempts at behaviour change that have been used in health studies to curb unhealthy behaviour such as smoking and heavy drinking (Butland et al, 2007). Two of the examples cited in the report (Behavioural Insights Team, 2010) were meant to encourage modal shift. One is the Step2Get initiative by Transport for London and Intelligent Health to incentivise children to walk to school by using swipe card technology, online gaming and rewards which have increased walking to school by $18 \%$. The second example is the introduction of bicycle hire schemes in major cities such as the one in London. It seems that bicycle retailers have reported significant increases in bicycle sales since the London scheme started. This might also be due to the opportunity to try a bicycle at a low price without large financial commitment. Neither of these examples has been subjected to rigorous evaluation to establish its cost effectiveness but it is known that the bicycle hire scheme does not cover its costs (Aldworth, 2011).

\section{THE EFFECTIVENESS OF POLICIES TO SHIFT PEOPLE FROM THE CAR TO ALTERNATIVE MODES}

The evidence reviewed in the two NICE studies covered interventions that directly encouraged walking and cycling rather than trying to reduce car use, with possible resulting increases in walking and cycling. There have been various schemes to reduce car use, but there is little evidence of which methods are effective, particularly in shifting people from cars

$13^{\text {th }}$ World Conference on Transport Research, Rio de Janeiro, Brazil, 15-18 July, 2013 


\section{Using transport policy to increase physical activity \\ MACKETT, Roger L}

to walking and cycling. Graham-Rowe et al (2011) reviewed the literature and found 3486 studies of possible relevance through a systematic search of the literature using key words and added a further 78 papers identified by supplementary searches. These were reduced systematically to 77 primary interventions which included car reduction measures. They concluded that the evidence base was weak, with only 12 evaluations regarded as methodologically strong. All the others were regarded as flawed because of the sampling methods used, lack of information about the comparison group, or because they were unsound in some other way.

The twelve papers that were regarded as methodologically strong by Graham-Rowe et al (2011) have been examined (Mackett and Brown, 2011). Of the twelve, only three considered walking and cycling. Bamberg (2006) looked at giving a free public transport ticket in Stuttgart in Germany, and found a slight increase in walking and a slight decrease in cycling, but the results were not statistically significant. Cervero et al (2002) looked at a car sharing scheme in San Francisco and found members were less inclined to walk and cycle but did find some shifts to walking and cycling in the longer run (1992). Hodgson et al (1998) looked at a public awareness campaign in Maidstone in Great Britain, but found no statistically significant changes in the number of trips by each mode.

The criteria used by NICE and Graham-Rowe et al (2011) were rigorous. The approach they adopted came from the medical and health fields where there are controlled environments, for example in drug trials, and it is not easy to apply the same rules to the evaluation of experiments such as major travel schemes. There are several reasons for this. Firstly, it probably needs a large travel scheme to show significant impacts and very few of these have been evaluated systematically (National Institute for Clinical and Health Excellence, 2008). The impact of the Cambridgeshire Guided Busway on walking and cycling is being monitored systematically and this should yield valuable results (Ogilvie et al, 2010). Secondly, it is very difficult and expensive to carry out such studies, particularly as they need to be carried out over a long period to establish all the impacts, some of which may be quite long term. Thirdly, it is, in practice, impossible to carry out such studies in a completely systematic way: in a medical experiment it is possible to control for differences between the two populations (those subject to the intervention and the control group), but this is not practical for transport schemes. However, not adopting such a rigorous approach to obtaining evidence may lead to spurious findings. For example, if new walking or cycling infrastructure is developed, it will almost certainly, be used and may be popular with users. However, if people are simply switching from walking or cycling elsewhere, then there is likely to be no significant increase in physical activity.

\section{CONCLUSIONS}

It has been shown that travel can contribute to physical activity through walking and cycling, and their decline over time may well have contributed to the decrease in levels of physical activity in recent years, with serious implications for the health of the population. It is likely that the growth in car use has been a significant factor in these trends. This raises the interesting question whether transport policies can be used to increase levels of walking and

$13^{\text {th }}$ World Conference on Transport Research, Rio de Janeiro, Brazil, 15-18 July, 2013 


\section{Using transport policy to increase physical activity \\ MACKETT, Roger L}

cycling, either directly or via changes in car use. It is clear from the two reviews by NICE that it believes that transport has a potential role to play, confirming the approach identified in the review of the literature for the British Department for Transport by Mackett and Brown (2011). It is clear from the NICE reviews that there have been many initiatives that appear to increase walking and cycling. However, there are many methodological weaknesses. In particular, while many of the studies appear to show increases in walking and/or cycling in the area in which the intervention has been applied, it is not clear whether these are new trips or transfers from elsewhere. To establish this would require a large randomised controlled trial, with a large sample, covering all trips over quite a long period, with some fairly subtle questions to establish whether the observed trips are new or transfers from elsewhere, possibly to other destination at a different time. It is also not clear how long the effects of the intervention last: for example, a new scheme may be accompanied by publicity and support for those taking part. Once these finish, walking and cycling may revert to their previous levels. Large schemes such as the London Congestion Charging scheme are likely to remain in place for the foreseeable future, and so, if they increase walking and cycling, are likely to be effective in the long run. However, they are expensive, and increases in walking and cycling are a side product in meeting the main objective, which is reducing traffic congestion in this case.

Overall, it can be argued that there is great potential for transport policies and the resulting actions to induce large changes in walking and cycling, but there needs to be more research into the long-term effectiveness of the various approaches.

\section{REFERENCES}

Adams, J. (2010) Prevalence and socio-demographic correlates of active transport in the UK: Analysis of the UK time use survey 2005. Preventive Medicine, 50 (4), 199-203.

Aldworth, N. (2011) Barclays cycle hire. Transport Economist, 38, 12-22.

Andersen, L.B., P. Schnohr, M. Schroll and H.O. Hein (2000) All-cause mortality associated with physical activity during leisure time, work, sports, and cycling to work. Archives of Internal Medicine, 160, 1621-1628.

Ashton-Graham, C. (2003) Network promotion: increasing bicycle use in Perth, Western Australia, in Tolley R. (ed) Sustainable Transport. Planning for Walking and Cycling in Urban Environments Woodhead Publishing, Cambridge.

Babtie Group (2001) Urban street activity in 20mph zones: Final Report, Report produced for the Department of Transport, Local Government and the Regions.

Bamberg, S. (2006) Is a residential relocation a good opportunity to change people's travel behavior? Environment and Behaviour, 38 (6), 820-840.

Behavioural Insights Team (2010) Applying Behavioural Insight to Health, Cabinet Office. http://www.cabinetoffice.gov.uk/resource-library/applying-behavioural-insight-health (accessed 20 October 2012).

Besser, L. M. and A. L. Dannenberg (2005) Walking to public transit: Steps to help meet physical activity recommendations. American Journal of Preventive Medicine, 29 (4), 273-280.

$13^{\text {th }}$ World Conference on Transport Research, Rio de Janeiro, Brazil, 15-18 July, 2013 


\section{Using transport policy to increase physical activity MACKETT, Roger L}

Blank, L. Jones, R., Buckley Woods, H. and Payne, N (2012) Systematic review and narrative synthesis of the effectiveness of local interventions to promote cycling and walking for recreational and travel purposes, School of Health and Related Research (ScHARR), University of Sheffield, Sheffield, http://www.nice.org.uk/nicemedia/live/13428/58990/58990.pdf (accessed 28 April 2013).

Boarnet, M.G., Anderson, C.L., Day, K., McMillan, T., and Alfonzo, M. (2005) Evaluation of the California Safe Routes to School legislation, American Journal of Preventive Medicine, 28, 134-140.

Bonsall, P.W., M. Conner, and A. Darnton. (2009) Thinkpiece 1: Influencing Individual Citizens. Final Report from the Institute for Transport Studies, University of Leeds.

Brockman, R. and K. R. Fox (2011) Physical activity by stealth? The potential health benefits of a workplace transport plan, Public Health, 125 (4), 210-216.

Butland, B., S. Jebb, P. Kopelman, K. McPherson, S. Thomas, J. Mardell, and V. Parry (2007) Foresight: Tackling Obesities: Future Choices - Project Report. Government Office for Science. http://www.bis.gov.uk/foresight/our-work/projects/publishedprojects/tackling-obesities (accessed 20 October 2012).

Cairns, S., (2006) Making School Travel Plans Work (Holmer Green First School), in Marsden, G.R. (ed) Wasted Miles, Wasted Money: A less congested, more energy efficient future, London: CICC Publications.

Cairns, S. (2011) Accessing Cars: Different ownership and use choices. RAC Foundation. http://www.liftshare.com/business/pdfs/RAC 142.pdf (accessed 20 October 2012).

Cairns, S., Hass-Klau, C. and Goodwin, P. (1998a) Traffic impact of highway capacity reductions: Assessment of the evidence - Luneburg, Landor Publishing, London.

Cairns, S., Hass-Klau, C. and Goodwin, P. (1998b) Traffic impact of highway capacity reductions: Assessment of the evidence - Orpington, Landor Publishing, London.

Cervero, R., N. Creedman, M. Pohan, M. Pai, and Y.-H. Tsai (2002) City CarShare: Assessment of short-term travel-behavior impacts. Institute of Urban and Regional Development, University of California at Berkeley, Berkeley, CA.

Cervero, R., A. Golub, and B. Nee (2007) City CarShare: longer-term travel demand and car ownership impacts. Transportation Research Record: Journal of the Transportation Research Board, 1992, 70-80.

Cope, A. (2011) Cycling in the city regions: delivering a step change, Sustrans.

Cope, A. (2009) Cycling Demonstration Towns: monitoring project report 2006 to 2009, Chartered Institute of Logistics and Transport.

Cope, A., Cairns, S., Fox, K., Lawlor, D., Lockie, M., Lumsdon, L., Riddoch, C., Rosen, P. (2003) The UK National Cycle Network: an assessment of the benefits of a sustainable transport infrastructure, World Transport Policy and Practice, 9 (1) 6-17.

Cycling Touring Club (1995a) More Bikes - Policy into Best Practice - Groningen, Godalming, Surrey.

Cycling Touring Club (1995b) More Bikes - Policy into Best Practice - Graz, Godalming, Surrey.

Department for Transport (2008) Making a cycling town: a compilation of practitioners' experiences from the Cycling Demonstration Town programme 2005-2009. 


\section{Using transport policy to increase physical activity MACKETT, Roger L}

http://webarchive.nationalarchives.gov.uk/20110407094607/http://www.dft.gov.uk/cyc lingengland/cycling-cities-towns/results/ (accessed 20 October 2012).

Department for Transport (2012) National Travel Survey 2010. http://www.dft.gov.uk/statistics/series/national-travel-survey/ (accessed 13 July 2012).

Durham County Council (2003) Saddler Street Road User Charge Scheme, Monitoring Report.

http://content.durham.gov.uk/PDFRepository/SaddlerStreetCongestionChargeReport. pdf (accessed 20 October 2012).

Ellaway, A., Macintyre, S., Hiscock, R. and Kearns, A. (2003) In the driving seat: Psychosocial benefits from private motor vehicle transport compared to public transport. Transportation Research Part F: Traffic Psychology and Behaviour, 6 (3), 217-231.

Gemzoe, L. (2001) Copenhagen on foot: thirty years of planning and development, World Transport Policy and Practice, 7 (4), 19-27.

Graham-Rowe E., S. Skippon, B. Gardner, and C. Abraham (2011) Can we reduce car use and if so, how? A review of available evidence. Transportation Research A, 45 (5) 401-418.

Harmer, C. and S. Cairns (2011), Carplus Annual Survey of Car Clubs 2010/11, Transport Research Laboratory, Crowthorne, 2011. http://www.trl.co.uk/online store/reports publications/trl reports/cat sustainability/re port carplus annual survey of car clubs 20102011.htm (accessed 20 October 2012).

Hartman, J. (1990) The Delft bicycle network, in Tolley R. (ed) The Greening of Urban Transport. Planning for Walking and Cycling in Western Cities, Belhaven Press, London.

Haskell, W. L., I. M. Lee, R. R Pate, K. E. Powell, S. N. Blair, B. A. Franklin, C. A. Macera, G. W. Heath, P. D. Thompson, and A. Bauman (2007) Physical activity and public health: Updated recommendation for adults from the American College of Sports Medicine and the American Heart Association. Medicine and Science in Sports and Exercise, 39 (8), 1423-1434.

Hodgson, F., T. May, M. Tight, and M. Conner (1998) Evaluation of the MIST travel awareness campaign: 2. The before and after study. Traffic Engineering and Control, $39,103-112$.

Inside Government (2013) Research and analysis Evaluation of the Cycling City and Towns programme, https://www.gov.uk/government/publications/evaluation-of-the-cyclingcity-and-towns-programme-interim-report (accessed 28 April 2013).

Kirby, T. (2001) 20mph Zones in Kingston Upon Hull, paper presented at the conference on 'Managing Vehicle Speeds for Safety: Latest Developments' held at Aston University, 19 September 2001.

Layfield, R., Chinn, L. and Nicholls, D. (2003) Pilot home zone schemes: evaluation of The Methleys, Leeds, Transport Research Laboratory, UK.

Mackett, R.L. (2003) Why do people use their cars for short trips? Transportation, 30 (3), 329-349.

Mackett R.L. and B. Brown (2011) Transport, Physical Activity and Health: Present knowledge and the way ahead, Scanning Study commissioned by the Department for

$13^{\text {th }}$ World Conference on Transport Research, Rio de Janeiro, Brazil, 15-18 July, 2013 


\section{Using transport policy to increase physical activity MACKETT, Roger L}

Transport, London, Great Britain, carried out through the UK Transport Research Centre (UKTRC) https://www.ucl.ac.uk/news/pdf/transportactivityhealth.pdf (accessed 20 October 2012).

Mackett R L and Ahern A A (2000) Potential for mode transfer of short trips: report on the analysis of the survey results, Report to the Department of the Environment, Transport and the Regions, September 2000.

Mackett, R.L., L. Lucas, J. Paskins, and J. Turbin (2005) The therapeutic value of children's everyday travel. Transportation Research Part A: Policy and Practice, 39 (2-3), 205219.

Mamoli, M. (2003) Promoting cycling in Italian cities: the case of Padua, in Tolley R. (ed) Sustainable Transport, Planning for Walking and Cycling in Urban Environments, Woodhead Publishing, Cambridge.

Marshall, S.J., S.S. Levy, C.E. Tudor-Locke, F.W. Kolkhorst, K.M. Wooten, M. Ji, C.A. Macera, and B.E. Ainsworth (2009) Translating physical activity recommendations into a pedometer-based step goal: 3000 steps in 30 minutes. American Journal of Preventive Medicine, 36 (5), 410-415.

Morrison, D., Thomson, H., Petticrew, M. (2004) Evaluation of the health effects of a neighbourhood traffic calming scheme, The Journal of Epidemiology and Community Health, 58, 837-840.

Murphy, M.H., S.N. Blair, and E.M. Murtagh (2009) Accumulated versus continuous exercise for health benefit: A review of empirical studies. Sports Medicine, 39 (1), 29-43.

Murray C.J.L. and A.D. Lopez (eds) (1996) The Global Burden of Disease: A Comprehensive Assessment of Mortality and Disability from Diseases, Injuries, and Risk Factors in 1990 and Projected to 2020. Harvard University Press, Cambridge.

National Institute for Clinical and Health Excellence (2008) Physical Activity and the Environment: Guidance on the promotion and creation of physical environments that support increased levels of physical activity. NICE Public Health Guidance 8. http://www.nice.org.uk/Guidance/PH8 (accessed 20 October 2012).

National Institute for Health and Clinical Excellence (2012) Walking and cycling: local measures to promote walking and cycling as forms of travel or recreation. Public Health Guidance 41. http://www.nice.org.uk/Guidance/PH41 (accessed 28 April 2013).

Newby, L. and Sloman, L. 1996, Small Steps, Giant Leaps: A review of the Feet First project and the practice and potential of promoting walking, Transport 2000 Trust, London.

NICE Public Health Collaborating Centre (2006a) Physical activity and the environment, Review 1: Transport, http://www.nice.org.uk/guidance/index.jsp?action=download\&o=34746 (accessed 30 April 2013).

NICE Public Health Collaborating Centre (2006b) Physical activity and the environment, Review 2: Urban planning and design, http://www.nice.org.uk/guidance/index.jsp?action=download\&o=34748 (accessed 30 April 2013).

Nottingham City Council (2012) Workplace parking levy. http://www.nottinghamcity.gov.uk/index.aspx?articleid=905 (accessed 20 October 2012).

$13^{\text {th }}$ World Conference on Transport Research, Rio de Janeiro, Brazil, 15-18 July, 2013 


\section{Using transport policy to increase physical activity MACKETT, Roger L}

Ogilvie D., S. Griffin, A. Jones, R. Mackett, C. Guell, J. Panter, N. Jones, S. Cohn, L. Yang, and C. Chapman (2010) Commuting and health in Cambridge: a study of a 'natural experiment' in the provision of new infrastructure. BMC Public Health, 10:703. http://www.biomedcentral.com/1471-2458/10/703 (accessed 20 October 2012).

Paffenbarger, J., R.T. Hyde, A.L. Wing, I.M. Lee, Jung, D.L., and J.B. Kampert (1993) The association of changes in physical-activity level and other lifestyle characteristics with mortality among men. New England Journal of Medicine, 328 (8), 538-545.

Painter, K. (1996) The influence of street lighting improvements on crime, fear and pedestrian street use, after dark, Landscape and Urban Planning, 35, 193-201.

Rowland, D., C. DiGuiseppi, M. Gross, E. Afolabi, and I. Roberts (2003) Randomised controlled trial of site specific advice on school travel patterns, Archive of Disease in Childhood, 88, 8-11.

Saelens, B.E., J.F. Sallis, and L.D. Frank (2003) Environmental correlates of walking and cycling: Findings from the transportation, urban design, and planning literatures. Annals of Behavioral Medicine, 25 (2), 80-91.

Santos, G. (2004) Urban road pricing in the UK: Road Pricing, Theory and Evidence. Research in Transportation Economics, 9, 251-282.

Scottish Office (1999) The Community Impact of Traffic Calming Schemes: Final Report, Prepared by Ross Silcock. The Scottish Office, Edinburgh.

Skjoeveland, O. (2001) Effects of street parks on social interactions among neighbors: a place perspective, Journal of Architectural and Planning Research, 8(2) 131-47.

Sloman, L. (2009) Analysis and Synthesis of Evidence on the Effects of Investment in Six Cycling Demonstration Towns, Chartered Institute of Logistics and Transport.

Sloman, L., S. Cairns, C. Newson, J. Anable, J. Pridmore and P. Goodwin (2010) The Effects of Smarter Choices Programmes in the Sustainable Travel Towns, Report to the Department for Transport, https://www.gov.uk/government/uploads/system/uploads/attachment data/file/4408/c hap1.pdf (accessed 28 April 2013).

Social Research Associates (1999) Bypass Demonstration Project. Further research and analysis in relation to attitudes to walking. Presented to Department of the Environment, Transport and the Regions, London.

Social Research Associates (2001) Gloucester City Council. Safer City Project - 2000, 2001, Social Research Associates, Leicester.

Space Syntax Ltd (2002) Millennium Bridge and Environs: Pedestrian impact assessment study, Space Syntax Ltd, London.

Space Syntax Ltd (2004a) Trafalgar Square: Comparative study of space use patterns following the re-design of the public space, Space Syntax Ltd, London.

Space Syntax Ltd (2004b) Paternoster Square: Comparative study of pedestrian flows following the re-design of the public space, Space Syntax Ltd, London.

Staunton, C., Hubsmith, D. and Kallins, W. (2003) Promoting safe walking and biking to school: The Marin County success story, American Journal of Public Health, 93 (9), 1431-1434.

Sustrans (2005) Monitoring Report 2005: Case Study: Ford Green, Stoke, available from http://www.sustrans.org.uk/assets/files/Info\%20sheets/Route\%20Monitoring\%20Rep ort\%202005.pdf. (accessed 16 April 2013).

$13^{\text {th }}$ World Conference on Transport Research, Rio de Janeiro, Brazil, 15-18 July, 2013 


\section{Using transport policy to increase physical activity MACKETT, Roger L}

Sustrans (2008) Bike It Review.

http://www.sustrans.org.uk/assets/files/Bike\%20lt/sustrans bike it review 2008 may08.pdf

Transport for London (2004) Central London Congestion Charging: Impacts Monitoring,

Second Annual Report. http://www.tfl.gov.uk/assets/downloads/Impacts-monitoringreport-2.pdf (accessed 16 April 2013).

Transport for London (2008) Central London Congestion Charging: Impacts Monitoring, Sixth Annual Report. http://www.tfl.gov.uk/assets/downloads/sixth-annual-impactsmonitoring-report-2008-07.pdf (accessed 20 October 2012).

Travelsmart 2011. Travelsmart Project Review. http://www.sustrans.org.uk/what-wedo/travelsmart

Troelsen, J., Jensen, S., Andersen, T. (2004). Evaluering af Odense-Danmarks nationale cykelby (in Danish - Evaluation of Odense-Denmark's national cycle city), Odense Kommune, Denmark.

Tudor-Locke, C., C. Leonardi, W.D. Johnson, P.T. Katzmarzyk, and T.S. Church (2011) Accelerometer steps/day translation of moderate-to-vigorous activity. Preventive Medicine, 53 (1-2), 31-33.

US Surgeon General (1996) Physical Activity and Health: A Report of the Surgeon General. US Department of Health and Human Services, Centers for Disease Control and Prevention, National Center for Chronic Disease Prevention and Health Promotion, Atlanta (GA)

Wagner, A., C. Simon, P. Ducimetière, M. Montaye, V. Bongard, J. Yarnell, A. Bingham, G. Hedelin, P. Amouyel, J. Ferrières, A. Evans, and D. Arveiler (2001) Leisure-time physical activity and regular walking or cycling to work are associated with adiposity and 5 year weight gain in middle-aged men: The PRIME study. International Journal of Obesity, 25 (7) 940-948.

Webster, D., Tilley, A., Wheeler, A., Nichols, S., Buttress, S. (2006) Pilot Home Zone Schemes: Summary of the Schemes, TRL Report 654, Transport Research Laboratory, Crowthorne.

Wener, R.E. and G.W. Evans (2007) A morning stroll: Levels of physical activity in car and mass transit commuting. Environment and Behavior, 39 (1), 62-74.

Wennberg, P., B. Lindahl, G. Hallmans, T. Messner, L. Weinehall, L. Johansson, K. Boman, and J.-H. Jansson (2006) The effects of commuting activity and occupational and leisure time physical activity on risk of myocardial infarction. European Journal of Cardiovascular Prevention \& Rehabilitation, 13, 924-930.

Zunft, H.J.F., D. Friebe, B. Seppelt, K. Widhalm, A.M.R. de Winter, M.D. Vaz de Almeida, J.M. Kearney, and M. Gibney (1999) Perceived benefits and barriers to physical activity in a nationally representative sample in the European Union. Public Health Nutrition, 2 (1A), 153-160. 